\title{
Tax Reform - Process Failures, Loopholes and Wealth Windfalls
}

\section{Citation}

Stephen E. Shay, Tax Reform - Process Failures, Loopholes and Wealth Windfalls (Nov. 21, 2017).

\section{Permanent link}

http://nrs.harvard.edu/urn-3:HUL.InstRepos:34377640

\section{Terms of Use}

This article was downloaded from Harvard University's DASH repository, and is made available under the terms and conditions applicable to Other Posted Material, as set forth at http:// nrs.harvard.edu/urn-3:HUL.InstRepos:dash.current.terms-of-use\#LAA

\section{Share Your Story}

The Harvard community has made this article openly available. Please share how this access benefits you. Submit a story.

Accessibility 
November 21, 2017

Working Draft

Comments are welcome

Tax Reform - Process Failures, Loopholes and Wealth Windfalls

Stephen E. Shay*

The GOP drive for a political victory on tax reform will come at a high cost if it succeeds. The extreme reduction in capital taxation will result in windfall wealth transfers to the already wealthy. Deficit expanding tax legislation will raise pressure for higher interest rates that hinder rather than enhance economic growth. Rushed tax legislation will be rife with undiscovered loopholes that increase the windfalls and scope of the deficit. Instead of the GOP-promised economic growth and benefits for the middle class there will be increased deficits and/or paygo reductions in Medicare, defense and discretionary spending.

\section{Process Failures}

But who would know? The GOP tax reform effort is being conducted under a process that (i) has held no hearings after proposals have been detailed and bill text released, ${ }^{1}$ (ii) has not allowed time for comments by bar associations or academics (not to mention affected industries), ${ }^{2}$ and (iii) has excluded review by critics (nonpartisan as well as partisan). In the single week's markup of the House proposal a newly minted provision was amended to respond to multinationals' complaints, a new revenue estimate was issued, and that same provision was amended again to fix more problems. ${ }^{3}$ Each passing day there are new discoveries of policy anomalies in the legislation. ${ }^{4}$.

\footnotetext{
* Senior Lecturer on Law at Harvard Law School. This is a working draft. I thank Reuven Avi-Yonah, Kim Clausing, Rebecca Kysar, Susan Morse and other persons who prefer to not be named for comments on earlier drafts. The views expressed in this paper are my own and do not reflect those of any university or organization that I am affiliated with or of any client for which I render pro bono or consulting services. I disclose certain activities not connected with my position at Harvard Law School, one or more of which may relate to the subject matter of this paper, at https://helios.law.harvard.edu/public/ConflictOfInterestReport.aspx?id=10794.

${ }^{1}$ The Senate Finance Committee held a hearing on October 3, 2017. The Committee did not disclose the provisions that would be included in the 247 page Joint Committee Staff description of the Chairman's Mark published on November 9, 2017 (JCX 51-17) or the 99 page description of the Chairman's modification to the mark published 5 days later (November 14) all for the November 15 mark-up. By all appearances, the October 3, 2017, hearing was irrelevant except to permit the Committee majority to say a hearing was held.

${ }^{2}$ This may be viewed as special pleading, since I am a member of the New York State Bar Association Tax Section ("NYSBA Tax Section") Executive Committee. No reports are more highly valued by policymakers' staffs to identify loopholes and technical glitches than those of the NYSBA Tax Section and its sister organization the American Bar Association Tax Section. There simply has not been time to bring those organizations' members to the table.

${ }^{3}$ See, e.g., successive House Ways and Means Committee amendments to H.R. 1, § 4303.

${ }^{4}$ See, e.g., Rebecca Kysar, The Senate Tax Plan Has a WTO Problem, available at https://medium.com/whateversource-derived/the-senate-tax-plan-has-a-wto-problem-guest-post-by-rebecca-kysar-31deee86eb99, last viewed Nov. 21, 2017.
} 
There also will be large and small loopholes in tax legislation adopted without adequate time to review and analyze bill text. This paper identifies just one loophole for multinationals in the "repatriation holiday" provisions that if not fixed could result in large revenue losses. The most egregious aspects of this repatriation holiday loophole can be addressed, but the existence of this loophole illustrates larger issues embedded in the bills' rate structures. There is a pervasive failure in the bill to introduce guardrails around substantial rate reductions that would effectively police the many new boundaries between rate differences that the bill creates. The planning that will result will further skew the benefit of the windfall for old capital under the bill to those with the highest incomes. And yet, there is no indication that Congress intends to permit widespread planning by corporations in this regard - meaning that the rush to "get reform done" will literally result in unintended consequences.

\section{The Repatriation Holiday Loophole}

This paper use the Senate proposal's tax rates as the basis for an example of the repatriation holiday loophole, but this strategy works under the House-passed bill's rates with a somewhat reduced benefit. ${ }^{5}$ The intuition underlying the loophole is simple. When an artificially low rate is available immediately before a rate twice as high $(5 \% \rightarrow 10 \%)$, taxpayers are given an incentive to accelerate income into the lower rate window. In this case, taxpayers are provided an incentive to accelerate realization of non-cash pre-effective date gains to increase unrepatriated profits of foreign subsidiaries and thereby take advantage of the especially low holiday rates on pre-effective date earnings not invested in cash. 6

Accelerating income into the pre-effective date period can be accomplished on a tax efficient basis by triggering realization (for U.S. but not local law tax purposes) of appreciation in a controlled foreign corporation's (CFC's) tangible business assets to step-up its adjusted tax bases for U.S. purposes. ${ }^{7}$ In post-effective date years the new legislation allows for an annual exemption for earnings equal to $10 \%$ times the basis of foreign tangible business assets held as of the effective date. ${ }^{8}$ Thus, to the extent a CFC is able to increase its basis of foreign tangible assets as of the effective date, it will achieve an increase in the annual exemption equal to $10 \%$ of that basis step-up each year until it is utilized in depreciation. The value of this exemption of

\footnotetext{
${ }^{5}$ As of the time of this writing, the Senate bill text was just made available.

${ }^{6}$ I have previously argued with co-authors against any rate relief for prior earnings. See J. Clifton Fleming, Jr., Robert J. Peroni, and Stephen E. Shay, "Getting from Here to There: The Transition Tax Issue," 154 TAX Notes 69 (April 3, 2017). In my October $3^{\text {rd }}$ Senate Finance Committee testimony, I recommended against use of different rates on pre-effective date earnings for a different reason than the loophole identified in this paper. I pointed out that taxpayers would take advantage of the separate reduced tax rates for earnings invested in cash and equivalents and for non-cash assets. See Testimony of Stephen E. Shay, Before the U.S. Senate Committee on Finance, Hearing on International Tax Reform 12 (Oct. 3, 2017). I understand that some companies have already invested some cash in non-cash assets. The loophole identified in this paper is a separate, additional reason to use a single, and much higher, rate of tax on pre-effective date foreign earnings.

${ }^{7}$ I use the colloquial term foreign subsidiary to refer to a "specified foreign corporation" as it is defined in the Senate mark-up document. See JCX 51-17 as modified by JCX 56-17.

${ }^{8}$ In the House bill the step-up would be the short-term AFR (1.27\% for October 2017) plus $7.0 \%$, or currently $8.27 \%$. The CBO projects that interest rates on Federal borrowing will increase over the next few years; if correct this would enhance the tax benefit under the House bill. See Edward Gamber, Projections of Interest Rates (Feb. 1, 2017), available at https://www.cbo.gov/publication/52391, last viewed Nov. 20, 2017.
} 
course is the effective tax rate that otherwise would be paid on the exempt income, which I will assume would be GILTI income, taxed at an effective rate of (10\%) times the exempt amount. The "cost" of this increased exemption would be the tax on the pre-effective date earnings that would be increased by the realization of gain. Under the Senate proposal these earnings would be taxed at a 5\% rate. This exempt return benefit of a step-up is in addition to the increased depreciation resulting from the step-up.

Under the rates in the Senate bill and current interest rates, this strategy would be very advantageous for the taxpayer. The strategy is illustrated in Example 1:

Example 1. Multinational IC has a foreign subsidiary (F Sub) that owns a foreign tangible business asset that has an adjusted basis of zero and a value of $\$ 1,000$. Before December 31,2017 , it triggers a realization event so that gain is realized for U.S. tax purposes. ${ }^{9}$ Because the gain is with respect to an asset used in the foreign subsidiary's business, it is not Subpart $F$ income. ${ }^{10}$ Accordingly, the $\$ 1,000$ of gain increases the pre-effective date earnings of the foreign subsidiary taxed at $5.0 \%$ or $\$ 50$.

There are two sources of benefit in post-effective date years from the step up of the tangible business asset. First, the step-up yields a depreciation deduction that reduces GILTI income taxed at 10\% (and at higher rates after 2025). ${ }^{11}$ The second benefit is that GILTI is further reduced by the tangible income return, which is $10.0 \%$ of the adjusted basis of the tangible business asset.

If the tangible business asset is a structure, it would have a 40 -year life under the alternative depreciation system (ADS) rules. ${ }^{12}$ On an undiscounted basis stepping up the basis of a structure depreciated over 40 years would be significantly net cash positive overall. ${ }^{13}$

But wait, there is more! Under both Senate and House bills, the tax on pre-effective date earnings may be paid in installments with significant back-loading. Only $40 \%$ of the tax must be paid in the first 5 years after the effective date of the legislation ( $8 \%$ of the tax a year). The remaining

\footnotetext{
${ }^{9}$ It would be necessary to choose appreciated assets that would avoid Section 197 anti-churning rules, but that should be quite feasible. In many cases, local taxes are low or may be mitigated if the realization transaction is a transfer under local tax law. It also would be possible to engage in a transaction that results in realization for U.S. tax purposes, but not local law tax purposes (e.g., using a "busted" section 351 transaction). In both cases it would be important to consider application of anti-abuse rules such as found in $\S \S 269$ or 7701(o) as appropriate, but many realization transactions would be outside the scope of those provisions. There also is regulatory authority in the tangible business asset return provisions to guard against asset stuffing, but they do not appear to address step-ups for property already owned.

${ }^{10}$ I.R.C. $\S 954(\mathrm{c})(1)(\mathrm{B})$ does not reach gains from the sale of property used in a trade or business. Treas. Reg. 1.954-2(e)(3)(ii). See Dover Corporation v. Commissioner, 122 T.C. 19 (2004).

${ }^{11}$ Tested income is reduced by allocable expenses. Senate bill, $\S 14201$, new $\S 951 \mathrm{~A}(\mathrm{c})(2)(\mathrm{A})(\mathrm{ii})$. For most assets, eligible for depreciation or amortization, including intangible assets, this benefit alone would justify a step-up under the Senate rate structure if the gain is not Subpart F income.

${ }^{12}$ Foreign use property is depreciated under the alternative depreciation rules of I.R.C. $\S 168(\mathrm{~g})$.

${ }^{13}$ The loophole works for property with lives shorter than 40-years as well but the benefit from the tangible business asset return would be smaller because of the depreciation of the asset. The depreciation benefit would be higher. As discussed in the paragraph, the deferral without interest of the tax payment expands the value of the loophole. It should be possible to pick property to maximize the benefit.
} 
$60 \%$ is paid in years $6(15 \%), 7(20 \%)$ and $8(25 \%)$. Consequently, the loophole is net cash positive for a structure in each year except year 8 when $25 \%$ of the tax is paid in a single year. But even this is not generous enough. The liability from the repatriation tax may be paid in these installments over 8 years without interest if the installment is paid on time. The Government is subsidizing the interest cost of the deferred tax payment, which further enhances the benefit of the step up.

And yet, there is even more! Throughout the bill, there is no recapture of indirect U.S. expenses that contributed to earning the foreign income for which the low rates are allowed. In essence, deductions were allowed at $35 \%$ for income that is taxed at $5 \%$. This free $30 \%$ deduction is a pure subsidy to earn the $5 \%$ income - a subsidy in many cases for tax avoidance. The failure to allocate or recapture U.S. deductions properly allocable to lower-rate foreign income is a problem that permeates the tax reform international provisions, despite the fact that it was discussed years ago in a critique of Chairman Camp's tax reform proposal as well as in my recent hearing testimony. ${ }^{14}$

Finally, the financial statement advantages of this loophole for public companies should not be overlooked. The benefit of the loophole will lower a company's tax rate for post-effective date years. The year in which the effective date occurs will see the revaluation of deferred tax assets and liabilities and many other changes to most corporations' book effective tax rates so the modest tax in the last pre-effective date year will be buried in transition noise.

The Senate proposal defends against measures to reduce pre-effective date earnings by using the lower of earnings as of November 9, 2017 or December 31, 2017, but it does not protect against increases to pre-effective date earnings. This planning highlights the poor policy decision to adopt a reduced tax rate on pre-effective date earnings that is even lower than the reduced rate adopted for post-effective date earnings. This flaw is in both the Senate and House bills.

It would be possible to limit the planning described above through any of several alternative drafting changes. ${ }^{15}$ A more substantive approach would be to use the same tax rate on old earnings as for post-effective date years and to charge interest on any installment payment of tax. This approach would nominally tax a step-up at a rate at least as high as the benefit. All that would mean, however, is that the built-in gain on the effective date of the tax reform changes will benefit from the new still low rates.

\section{Wealth Transfers to the Already Wealthy}

The tax planning described above highlights a more fundamental issue, which is the tax reform wealth windfall for existing shareholders of corporations and owners of pass through businesses.

\footnotetext{
${ }^{14}$ See Stephen E. Shay, J. Clifton Fleming, Jr., and Robert J. Peroni, “Territoriality in Search of Principles and Revenue: Camp and Enzi," 141 TAX NOTES 173 (2013); Shay Testimony, supra note 6, at 11-12.

${ }^{15}$ Time and space do not permit full elaboration, but drafters should recall that it is possible using the infinitely flexible check-the-box entity classification regulations to implement some tax avoidance plans retroactively for up to 75 days. See Treas. Reg. $\$ 301.7701-3(c)(1)($ iii). Forward looking companies, then, may have established structures that could create pre-effective date earnings for up to 74 days after any date established in the bill unless the bill draft specifically deals with this issue in the drafting of the effective date for a provision. The House-passed bill has not done that in $\S 4004$.
} 
Pre-effective date unrealized but built-in gain of corporations will be taxed at $20 \%$ instead of $35 \%$. That is baked into the structure of the legislation - corporate rate reduction is President Trump's primary ask. This benefit benefits already existing investment, not new investment.

Because the market will capitalize the benefit of reduced rates into share prices, shareholders can sell their shares in the short term and reap the benefit of the rate reduction on existing appreciation. ${ }^{16}$ An estimated $35 \%$ of the benefit from reduced rates will go to foreign shareholders. ${ }^{17}$

The value of all appreciated business property goes up when the applicable business tax rate goes down, but pre-effective date appreciation only is picked up in the Joint Committee distribution tables to the extent there is realization within the budget period. Moreover, this element of income should not be distributed at all to labor who do not benefit from the windfall to existing investment. Pre-effective date appreciation that is not realized in the budget period is not even taken into account in distribution tables - and it goes overwhelmingly to those with the highest incomes. $^{18}$

\section{Conclusions}

The corporate rate reduction and the reduced rate for pre-effective date foreign earnings are not justified on policy grounds in the first place, but this tax giveaway should not be expanded by loopholes in the legislation passed in a rush by both houses of Congress. Short-term political exigencies are not an excuse to adopt legislation that affords tax avoidance opportunities that will yield unintended revenue losses and undermine taxpayer faith in the tax system and government. That is the strategy of cynics or ideologues not leaders.

The GOP tax reform tax cuts for the middle class are trivial in relation to enormity of the wealth windfall to the already wealthy from the legislation's rate cuts. Loopholes like that described in this paper are a sideshow compared to this vast wealth transfer on old capital, but, incredibly, they will enhance it. Congress should slow down, hold hearings, collect comments and think, before plunging ahead with such misguided legislation.

\footnotetext{
${ }^{16}$ The Tax Policy Center finds that over $90 \%$ of capital gain rate benefit goes to the top income quintile, over $73 \%$ goes to the top $1.0 \%$ and over $55 \%$ of the benefit goes to the top $0.1 \%$. Urban-Brookings Tax Policy Center, Table T17-0137 (Apr. 18, 2017), available at http://www.taxpolicycenter.org/model-estimates/individual-income-taxexpenditures-april-2017/t17-0137-tax-benefit-preferential, last viewed Nov. 20, 2017.

${ }^{17}$ Steven M. Rosenthal, Foreign Investors Win Big, Tax-free (Oct. 31, 2017), available at http://www.taxpolicycenter.org/taxvox/foreign-investors-win-big-tax-free, last viewed Nov. 20, 2017.

${ }^{18}$ See Urban-Brookings Tax Policy Center, Table T17-0137, supra note 16.
} 